\title{
Wybrane zagadnienia związane z unifikacją konstrukcji ostoi wagonu pasażerskiego typu $Z$
}

\begin{abstract}
Obecnie konstrukcje nośne ostoi wagonów osobowych dopasowuje się indywidualnie w zależności od zastosowanego wyposażenia. Powoduje to bardzo duża różnorodność rozwiqzań. W IPS 'Tabor" podjęto próbę ujednolicenia tych konstrukcji. W artykule przedstawiono koncepcje unifikacji konstrukcji nośnej ostoi wagonu osobowego. Omówiono dotychczasowe rozwiazania konstrukcyjne oraz zaproponowano zmiany zwiazane z unifikacja ostoi. Zaprezentowano wyniki obliczeń wytrzymatości czesści skrajnej ostoi.
\end{abstract}

\section{Wprowadzenie}

Obecnie najpowszechniej stosowanymi wagonami pasażerskimi są wagony typu Z. Sa to wagony o całkowitej długości pudła wraz ze zderzakami wynoszącej $26,4 \mathrm{~m}$ oraz rozstawie czopów skrętu $19,0 \mathrm{~m}$. Wymagania stawiane wagonom pasażerskim typu $\mathrm{Z}$ dopuszczonym do ruchu międzynarodowego określaja przepisy kart UIC: 567[1] i 567-2[2].

Karta UIC 567-2[2] wprowadza podział wagonów typu $\mathrm{Z}$ na dwie odmiany:

a) Z1, który musi być konstrukcyjnie przystosowany do prędkości $200 \mathrm{~km} / \mathrm{h}$,

b) Z2, który musi być konstrukcyjnie przystosowany do prędkości $160 \mathrm{~km} / \mathrm{h}$.

Historycznie rzecz ujmując w pierwszej kolejności projektowano wagony typu Z2, a w miarę wzrostu wymagań stawianych komfortowi podróżowania m.in. zwiększenie prędkości jazdy pociagów, podwyższenie standardu wyposażenia itp. zaczęły pojawiać się wagony typu $\mathrm{Z} 1$.

W świetle wymagań UIC stawianych obecnie wagonom pasażerskim typu $\mathrm{Z}$ podział na odmiany sprowadza się właściwie do zróżnicowania urządzeń biegowych, a więc przede wszystkim wózków i osprzętu z nimi związanego. Natomiast wyposażenie pudła powinno być identyczne, a w każdym razie bardzo zbliżone. W konstrukcji pudła należałoby więc przewidzieć możliwość zamontowania wszystkich wymaganych urządzeń. Wspomniane wyżej wyposażenie wagonu pasażerskiego, które obejmuje urządzenia gwarantujące $\mathrm{z}$ jednej strony bezpieczeństwo jazdy (m.in. urządzenia hamulcowe i elektryczne), a z drugiej strony odpowiedni komfort (m.in. urządzenia klimatyzacyjne oraz sanitarne) są najczęściej przymocowane do podwozia wagonu. Różnorodność konfiguracji tych urządzeń i sposobu ich mocowania oraz związanego osprzętu powoduje konieczność każdorazowego projektowania ostoi dla kolejnych wersji wagonów pasażerskich.

Wobec powyższego w IPS 'Tabor", który od wielu lat zajmuje się projektowaniem wagonów osobowych, podjęto próbę przeanalizowania możliwości ujednolicenia konstrukcji ostoi tak, aby można stosować je niezależnie od przeznaczenia i wyposażenia wagonu pasażerskiego.

\section{Ogólna budowa konstrukcji nośnych istnieją- cych wagonów pasażerskich}

Konstrukcje nośne pudeł istniejących wagonów pasażerskich mają tradycyjną budowę szkieletową, składajacca się z pospawanych profili walcowanych lub giętych tworzących szkielet, pokryty poszyciem z blach o różnorodnym przekroju poprzecznym (np. płaskie, ryflowane, faliste). Podstawowym materiałem stosowanym do budowy tych konstrukcji jest stal i to zarówno węglowa $\mathrm{z}$ dodatkiem $\mathrm{Cu}$ (S235JRCu3, S235JRG2Cu3) jak i stopowa o podwyższonej wytrzymałości i odporności na korozję (S355JOCu3) oraz trudnordzewiejąca (S355JOW).

Od szeregu lat utrzymuje się tendencja odstępowania od konstrukcji szkieletowych na rzecz skorupowych, umożliwiających obniżenie masy pudeł przy zachowaniu podstawowych parametrów konstrukcyjnych [3,4 i 5]. W takim przypadku pudło zbudowane jest z szeregu połączonych ze sobą segmentów różnorodnych kształtów i rozmiarów, stanowiących określone fragmenty pudła. Każdy segment jest konstrukcją najczęściej wielościenną, tworzącą profile zamknięte. W przypadku stosowania materiałów stalowych segmenty te wykonuje się np. na drodze zgrzewania ze sobą odpowiednio ukształtowanych arkuszy blach. Dla konstrukcji ze stopów aluminium są to najczęściej sekcje wytłaczane wypływowo. Segmenty są połączone między sobą za pomocą spawania. Takie rozwiązania dotyczą generalnie pojazdów metra, kolei podmiejskich czy szybkobieżnych zestawów wagonowych, które jeżdżą w określonych składach.

W przypadku składów dalekobieżnych tworzonych $\mathrm{z}$ różnorodnych wagonów budowa pudeł pozostaje raczej tradycyjna, przy czym znacznie cześciej korzysta się z materiałów innych niż stal węglowa, a mianowicie stali nierdzewnej i stopów aluminium.

Konstrukcję nośną pudła wagonowego najogólniej można podzielić na dwie części składowe: podwozie i nadwozie. Podwozie wagonu stanowi ostoja wraz $\mathrm{z}$ podłogą stalowa, natomiast w skład nadwozia wchodzą ściany boczne, czołowe oraz dach. 


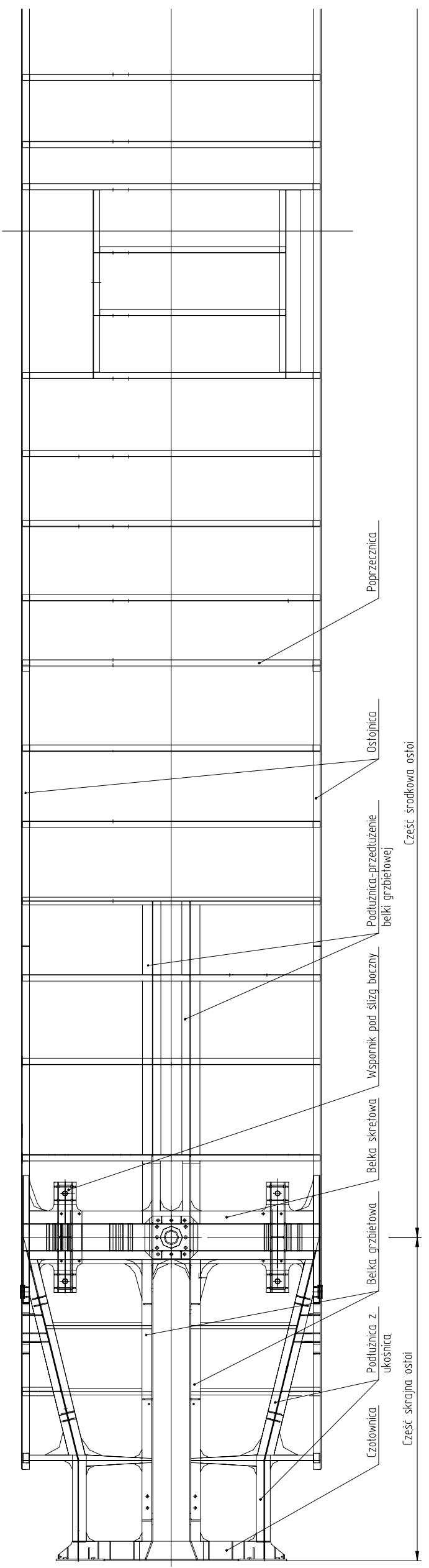

Ostoję dla potrzeb porządkowych dokumentacji konstrukcyjnej formalnie podzielono na trzy części: środkową i dwie skrajne. Przykładowy widok ogólny ostoi przedstawiono na rys. 1 .

Głównymi elementami nośnymi ostoi są dwie ostojnice, wykonane $\mathrm{z}$ ceowników walcowanych, rozstawionych na szerokości wagonu i biegnące wzdłuż prawie całej jego długości. Ostojnice powiązane są ze sobą przede wszystkim dwiema belkami skrętowymi oraz szeregiem poprzecznic.

Belki skrętowe stanowią zasadniczy element, za pomocą którego pudło połączone jest $\mathrm{z}$ wózkami. Muszą być konstrukcyjnie przystosowane do przeniesienia znacznych obciążeń powstających w eksploatacji wagonu, i to zarówno pionowych jak i wzdłużnych. $\mathrm{Z}$ tego też powodu, dla zachowania odpowiednich parametrów wytrzymałościowych, belki skrętowe wykonane są $\mathrm{w}$ postaci przekrojów zamkniętych spawanych z blach (konstrukcje skrzynkowe). Szczegółowe rozwiązania konstrukcyjne zależą ściśle od typu zastosowanego wózka, a przede wszystkim od sposobu połączenia go z pudłem.

$\mathrm{Na}$ poprzecznice zastosowano głównie ceowniki gięte, niejednokrotnie $\mathrm{w}$ rejonie mocowania na podwoziu elementów wyposażenia, zespawane razem tworzące przekrój zamknięty.

W skrajnych częściach ostoi w osi wzdłużnej wagonu znajduje się belka grzbietowa wykonana $\mathrm{z}$ dwóch ceowników walcowanych, służąca głównie do przeniesienia sił rozciągających powstających w aparacie ciegłowym.

$\mathrm{Na}$ końcach belek grzbietowych, będących jednocześnie końcami ostoi, znajdują się czołownice wykonane $\mathrm{w}$ postaci przekroju otwartego spawanego $\mathrm{z}$ blach, przeznaczone do przejęcia sił ściskających $\mathrm{w}$ zderzakach.

W omawianym rejonie pomiędzy czołownicą a belką skrętową wprowadzono na przedłużeniu osi zderzaka podłużnice, która przechodząc $\mathrm{w}$ ukośnicę dochodzi do węzła połączenia belki skrętowej z ostojnicą. Wykonano ją w postaci dwuteownika spawanego $\mathrm{z}$ blach.

Przedłużenie belek grzbietowych za belką skrętową w kierunku środka wagonu stanowią podłużnice wykonane w postaci kształtownika giętego (np. zetownika) kończące się na trzeciej lub czwartej poprzecznicy za belką skrętową.

Całość ostoi pokryta jest podłogą stalową, przy czym obszary pomiędzy czołownicami a belkami skrętowymi wykonane są $\mathrm{z}$ blach płaskich o grubości 2 i $3 \mathrm{~mm}$. Pomiędzy belkami skrętowymi zastosowano blachę falistą (ryflowana) o grubości $1 \mathrm{~mm}$.

W rejonach rozmieszczenia urządzeń wyposażenia podwagonowego wprowadzono, zwłaszcza w części środkowej ostoi, szereg dodatkowych elementów konstrukcyjnych (podłużnic, wsporników itp.) umożliwiających zamocowanie tych urządzeń. Wpro- 
wadzenie ich powoduje zaburzenia w rozkładzie poprzecznic, co wyraźnie widać na rys. 1 .

Szkielety ścian bocznych, czołowych i dachu wykonane są przede wszystkim z kształtowników giętych $\mathrm{z}$ blach, jedynie lokalnie ze względu na wymagania wytrzymałościowe wzmacnianych, jak w przypadku ściany czołowej, profilami walcowanymi. Poszycia ścian bocznych, czołowych i skrajnych części dachu wykonane są z blach płaskich natomiast poszycie części środkowej dachu z blachy ryflowanej.

\section{Analiza budowy konstrukcji nośnych pod kątem planowanej unifikacji}

Zunifikowanie budowy ostoi wagonu pasażerskiego typu $Z$ jest możliwe raczej pod warunkiem wprowadzenia budowy modułowej ostoi.

Modułowość budowy ostoi umożliwia przede wszystkim ułatwienie wykonania ostoi oraz uzyskanie wielu konfiguracji rozmieszczenia elementów nośnych zwłaszcza w części środkowej ostoi.

O kształcie modułowej budowy ostoi decydować będzie przede wszystkim sposób połączenia i współpracy ze wszelkiego rodzaju zespołami wyposażenia, co można wstępnie określić opierając się na posiadanej wiedzy o dotychczasowych konstrukcjach wagonów pasażerskich.

Podwozie $\mathrm{z}$ nadwoziem zespawane są wzdłuż ostojnic i czołownic. W przypadku zachowania szkieletowej budowy pudła wagonowego, w zunifikowanej ostoi elementy te będą musiały również występować.

Na podwoziu (ostoja+podłoga stalowa) wewnątrz pudła mocowane jest wyłożenie podłogi, a na niej ścianki działowe i inne elementy wyposażenia, które nie mają decydującego wpływu na kształt modułowej budowy ostoi.

W części skrajnej ostoi mocowane są urządzenia pociągowo-zderzne, których położenie i sposób zabudowy ściśle określają międzynarodowe przepisy kolejowe. $\mathrm{W}$ tej cześci ostoi realizowane jest również połączenie z wózkiem, od typu którego zależy konstrukcja belki skrętowej.

Do podwozia od dołu przymocowany jest szereg urządzeń o znacznych rozmiarach i masach niezbędnych do prawidłowego funkcjonowania wagonu. Należą do nich:

- urządzenia klimatyzacji wnętrza, a więc agregat klimatyzacyjny oraz agregat sprężarki i skraplacza,

- urządzenia zasilania w energię elektryczną tj. przetwornica statyczna oraz skrzynia akumulatorów i bezpieczników,

- kontener hamulcowy, w którym zabudowano tablice pneumatyczna łacznie ze zbiornikami powietrza i tablicami przestawczymi,

- zbiornik nieczystości układu WC o zamkniętym obiegu.

Modułowa budowa ostoi powinna zapewniać wystarczającą wytrzymałość dla przeniesienia podstawo- wych obciążeń powstających podczas eksploatacji.

4. Zróżnicowanie budowy wagonów w zależności od zastosowanego wyposażenia

W dotychczasowych rozwiązaniach konstrukcyjnych stosowano bardzo różnorodne wyposażenia wagonów, co pociagało za sobą indywidualne przystosowywanie ustroju nośnego do mocowania poszczególnych urządzeń.

Przyczyniło się to do powstania m.in. szeregu konstrukcji belek skrętowych umożliwiających połączenie z różnymi typami wózków.

Dla tradycyjnego sposobu połączenia pudła $\mathrm{z}$ wózkiem, jakim jest czop skrętu i ślizgi boczne, z którym mamy do czynienia w przypadku wózków np. 4ANh, SGP-300 lub MD-524 wykorzystywana jest belka skrętowa o konwencjonalnej konstrukcji.

$\mathrm{W}$ przypadku wagonu typu $150 \mathrm{~A}$ opartego na wózku $11 \mathrm{ANa}$, który $\mathrm{w}$ połączeniu z pudłem nie posiada tradycyjnego czopa skrętu, w dolny pas belki skrętowej należało wprowadzić wielkogabarytowe sprężyny zawieszenia drugiego stopnia, co wymagało zaprojektowania w tym miejscu dużych otworów. Kształt dotychczasowych belek skrętowych musiał więc ulec znacznej zmianie. Ten sposób połączenia wymagał również wprowadzenia $\mathrm{w}$ ostoi dodatkowego wspornika do przekazania sił wzdłużnych.

W przypadku wagonów typu 305A, gdzie zastosowano wózki typu $25 \mathrm{ANa}$ dostosowane do ruchu normalno- i szerokotorowego, w konstrukcji belki skrętowej musiano zaprojektować uniwersalne wsporniki pod ślizgi boczne. Schematycznie przedstawiono to na rys. 1.

Z porównania wózków wynika, że oprócz wagonu typu $150 \mathrm{~A}$ na wózkach $11 \mathrm{ANa}$ wszystkie pozostałe posiadają bardzo zbliżoną do siebie konstrukcję połączenia pudła z wózkiem.

Urządzenia podwoziowe w części środkowej wagonu mocowane są do wsporników przyspawanych do konstrukcji ostoi. Wymaga to jednak lokalnych zmian w układzie poprzecznic, a niejednokrotnie wprowadzenia dodatkowych elementów umożliwiających mocowanie. Prowadzi to do sytuacji, w której dla każdego typu urządzenia należy indywidualnie dopasować ostoję w rejonie mocowania.

W ostatnio projektowanych wagonach sypialnych typu 305Ad, w celu ułatwienia mocowania urządzeń do podwozia, wprowadzono specjalne ramy wykonane wraz z odpowiednimi wspornikami niezależnie od ostoi i następnie przyspawane do ostojnic. W miejscu połączenia ramy z ostoją na ceowniku ostojnicy wybudowano odpowiedni wspornik umożliwiający przyspawanie końców ram. Zaproponowane rozwiązanie może stanowić podstawę do rozwoju idei modułowości konstrukcji ostoi.

\section{Koncepcja unifikacji konstrukcji ostoi wagonu}

Biorąc pod uwagę dotychczasowe spostrzeżenia na temat konstrukcji ostoi wagonu pasażerskiego jak i jego wyposażenia, można wstępnie przedstawić 


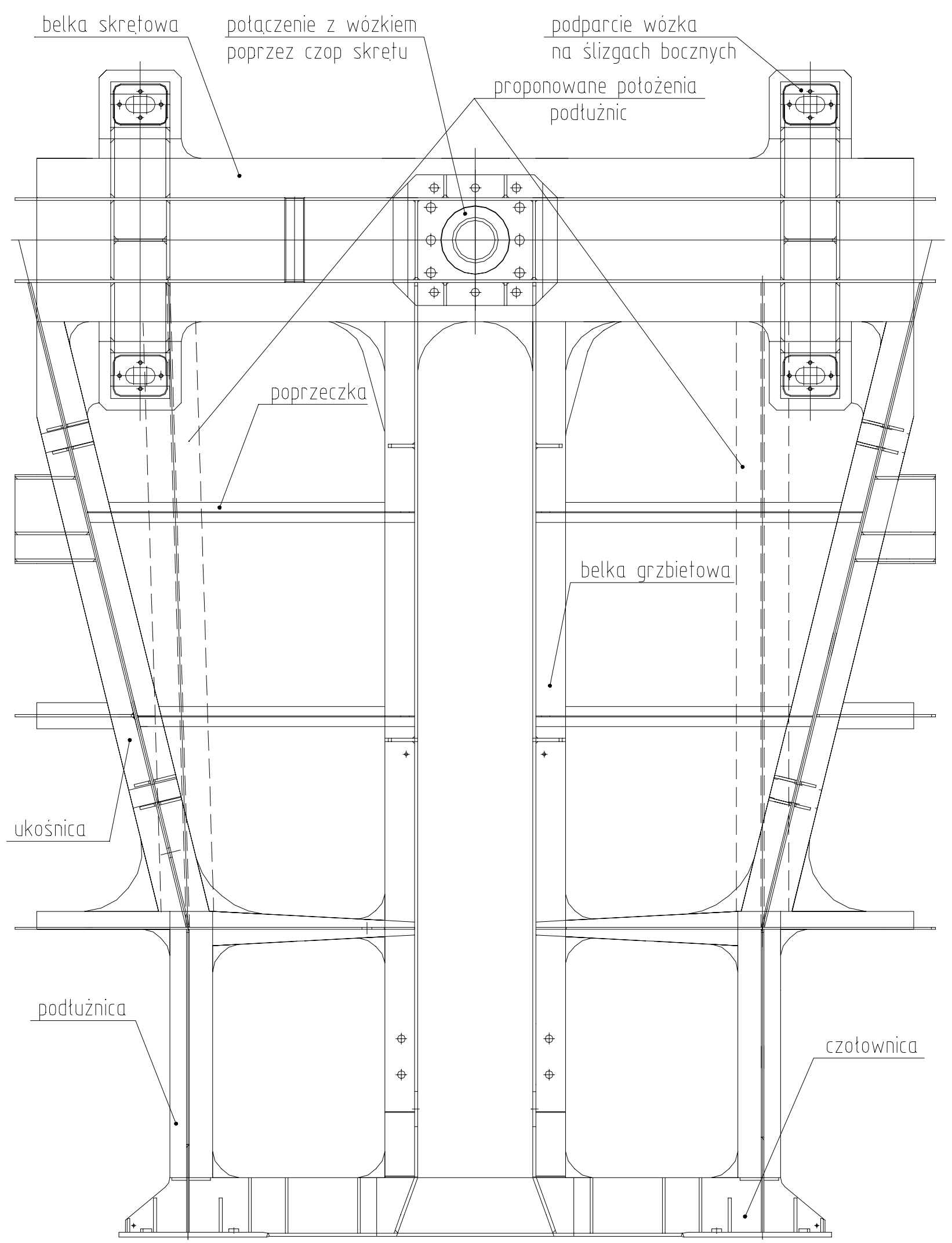

Rys. 2. Proponowana konstrukcja modułu skrajnego 
koncepcję unifikacji.

Należy jednak zdać sobie sprawę $\mathrm{z}$ faktu, że jest to tylko propozycja, gdyż problem można rozwiązywać na wiele sposobów. Najbardziej właściwe byłoby zachowanie ogólnego schematu dotychczasowego układu nośnego ostoi, a więc takiego jak przedstawiono na rys. 1. Pozwoliłoby to na szerokie wykorzystanie istniejących rozwiązań konstrukcyjnych podzespołów.

Podstawowym założeniem proponowanego rozwiązania jest odstąpienie od dotychczasowego podziału ostoi na trzy części (środkowa i dwie skrajne). Zakłada się, że głównymi elementami nośnymi są dwie ostojnice, o długości i rozstawie takim samym jak dotychczas. Różnica polega jedynie na tym, że miałyby być one wykonane jako jeden element np. z ceownika walcowanego C200.

Pomiędzy ostojnice byłyby wstawiane pozostałe elementy pogrupowane w moduły.

Moduł skrajny mógłby składać się z belki skrętowej, dwóch belek grzbietowych, czołownicy i dwóch podłużnic równoległych do belki grzbietowej wraz z ukośnica, co przykładowo przedstawiono na rys. 2 . Poprzeczki służące do podparcia blachy podłogowej mogłyby być przyspawane już po połączeniu modułu $\mathrm{z}$ ostojnicami.

Konstrukcja takiego modułu uzależniona byłaby przede wszystkim od typu wózka, który wpływa na kształt ostoi w rejonie połączenia z pudłem. Można by więc stworzyć szereg modułów dla poszczególnych typów wózków. Przykład na rys. 2 dostosowany jest do wózka typu 25ANa.

Połączenie modułu z ostojnicami mogłoby być zrealizowane poprzez przyspawanie bezpośrednio do górnego pasa i środnika ostojnicy, natomiast $\mathrm{w}$ rejonie dolnego pasa do specjalnych wstawek zamocowanych na ostojnicy.

Poważnym utrudnieniem $\mathrm{w}$ takim rozwiązaniu konstrukcyjnym modułu skrajnego jest, ze względu na ograniczony dostęp, spawanie $\mathrm{w}$ rejonie połączenia ukośnicy i belki skrętowej z ostojnica. Aby tego uniknąć proponuje się zmienić położenie ukośnicy tak, aby stanowiła przedłużenie podłużnicy lub w przypadku modułu dla wózka typu $25 \mathrm{ANa}$ odchylić nieznacznie od osi podłużnicy. Schematycznie przedstawiono to na rys. 2 linia przerywana.

Oczywiście poprzeczki należałoby dopasować do aktualnego położenia podłużnicy. Proponowane rozwiązanie wstępnie przeanalizowano pod względem wytrzymałościowym. Wynik analizy zamieszczono w dalszej części niniejszego artykułu.

Za belką skrętową w kierunku do środka wagonu w dotychczasowych konstrukcjach jest przedłużenie belki grzbietowej sieggające do czwartej poprzecznicy. Rejon ten można by również zastapić odpowiednim modułem, który roboczo można nazwać środkowym.

W pozostałej przestrzeni między belkami skrętowymi należy zarezerwować miejsce na przymocowa- nie modułów służących do zabudowy urządzeń podwoziowych. Można je wykonać np. w postaci ram. Dla każdego stosowanego typu urządzenia można zaprojektować ramę do jego mocowania. Ich położenie wzdłuż ostojnic można dostosować do indywidualnych potrzeb danego typu ostoi i rozplanowania wagonu.

Pozostałe wolne rejony należałoby wypełnić typowymi poprzecznicami koniecznymi do połączenia w kierunku poprzecznym ostojnic oraz podparcia blachy podłogi stalowej.

Połączenie modułu środkowego oraz wspomnianych ram i poprzecznic z ostojnicami można zrealizować za pomocą wsporników.

Uzyskany szkielet ostoi byłby pokryty blachą podłogowa, przy czym tak jak dotychczas w skrajnych częściach ostoi jest to blacha płaska, a pomiędzy belkami skrętowymi blacha falista.

\section{Analiza wytrzymalościowa zmiany położenia ukośnicy w części skrajnej ostoi}

Proponowana zmiana położenia ukośnicy w części skrajnej ostoi wymaga sprawdzenia, czy ostoja posiada wystarczającą wytrzymałość na przeniesienie podstawowych obciążeń eksploatacyjnych. Ocenę tą oparto na porównaniu wielkości odkształceń ostoi przed i po zmianie.

Położenie ukośnicy decyduje o sposobie przekazania głównie obciążeń wzdłużnych, a więc na wytrzymałość omawianego rejonu mają wpływ: ściskanie w osi zderzaków lub sprzęgu siłą $2,0 \mathrm{MN}$ oraz rozciaganie w osi sprzegu siłą $1,5 \mathrm{MN}$.

Analizę wytrzymałości przeprowadzono metodą elementów skończonych (MES). Model obliczeniowy ograniczono tylko do ostoi pokrytej blachą podłogi stalowej. Oddziaływanie pudła i wózka uwzględniono w odpowiednim doborze warunków brzegowych. Rozpatrzono dwie wersje ostoi: $\mathrm{z}$ dotychczasowym oraz proponowanym położeniem ukośnicy. Model obciążono siłami ściskającymi przyłożonymi w osi zderzaków. Sposób obciążenia oraz warunki brzegowe dla obu modeli przyjęto identyczne.

Porównując odkształcenia konstrukcji dla obu wersji ostoi można dojść do wniosku, że różnice między nimi są bardzo nieznaczne i występują, czego należało się spodziewać, jedynie $\mathrm{w}$ rejonie połączenia belki skrętowej, podłużnicy i ostojnicy. „Wyprostowanie” ukośnicy spowodowało bowiem zmianę rozkładu obciążeń w tym obszarze, co wpłynęło głównie na przemieszczenia $\mathrm{w}$ kierunku poprzecznym $\mathrm{i}$ to one powinny decydować o różnicy $\mathrm{w}$ rozkładzie przemieszczeń całkowitych. Omówiono to poniżej.

Maksymalne przemieszczenie ostoi w kierunku wzdłużnym występuje $\mathrm{w}$ czołownicy $\mathrm{w}$ rejonie zderzaka $\mathrm{i}$ wynosi dla ostoi $\mathrm{w}$ wersji $\mathrm{z}$ ukośnica $\mathrm{f}_{\mathrm{Zmax}}=$ $11,514 \mathrm{~mm}$, a dla wersji z podłużnicą $\mathrm{f}_{\mathrm{Zmax}}=11,484 \mathrm{~mm}$. $\mathrm{W}$ rejonie połączenia belki skrętowej, podłużnicy i ostojnicy, analizowane przemieszczenia dla obu wersji 
wahają się w granicach $8,9 \div 9,2 \mathrm{~mm}$. Widać więc, że zróżnicowanie jest niewielkie (maksymalnie około 3\%) i można uznać rozkłady przemieszczeń w kierunku wzdłużnym za porównywalne.

Wartości przemieszczeń w kierunku poprzecznym są znacznie mniejsze niż w kierunku wzdłużnym i wahają się $\mathrm{W}$ omawianym rejonie dla ostoi $\mathrm{W}$ wersji $\mathrm{Z}$ ukośnicą $\mathrm{w}$ granicach $-0,40 \div+0,25 \mathrm{~mm}$, a dla wersji $\mathrm{z}$ podłużnicą $\mathrm{w}$ granicach $-0,40 \div+0,35 \mathrm{~mm}$. Znak ,,-, i „+" informuje o zwrocie przemieszczenia. Zasadnicza różnica między wersjami polega na odmiennym rozkładzie przemieszczeń poprzecznych. Należy jednak zdawać sobie sprawę $\mathrm{z}$ faktu, że wartości przemieszczeń $\mathrm{w}$ tym kierunku stanowią znikomą część przemieszczeń w kierunku wzdłużnym. $\mathrm{Z}$ tego też powodu mimo występowania różnic $\mathrm{w}$ rozkładzie przemieszczeń poprzecznych, ich wpływ na rozkład przemieszczeń całkowitych jest nieznaczny.

$\mathrm{Na}$ podstawie przeprowadzonej analizy można wstępnie stwierdzić, że ostoja z proponowaną zmianą położenia ukośnicy posiada porównywalną wytrzymałość $\mathrm{z}$ ostoją $\mathrm{w}$ dotychczasowym rozwiązaniu. Ostateczne podjęcie decyzji o zastosowaniu propozycji powinno być poparte wynikami analizy wytrzymałościowej całej konstrukcji nośnej pudła wagonu pasażerskiego.

\section{Kierunki rozwoju unifikacji}

Z zagadnieniem unifikacji konstrukcji ostoi wiąże się nierozerwalnie problem zasilania różnorodnych urządzeń mocowanych na wagonie. Wymagają one doprowadzenia wielu instalacji m.in. pneumatycznych i elektrycznych. W dotychczasowych konstrukcjach są one prowadzone za pomoca rur przede wszystkim stalowych bądź aluminiowych. W niewielu miejscach stosuje się elastyczne rury z tworzyw sztucznych.

$\mathrm{W}$ ostatnio projektowanych wagonach instalacja pneumatyczna zapewniająca zasilanie układu hamulcowego oraz łącząca kontener hamulcowy z układem hamulcowym na wózkach przebiega w części środkowej wagonu poniżej poziomu dolnej płaszczyzny ostoi. W częściach skrajnych ostoi, zwłaszcza w rejonach połączenia z wózkami, przechodzi przez elementy nośne ostoi tj. belkę skrętową i czołownicę. Starając się zachować dotychczasowy układ można pokusić się o pewną unifikację: przygotowanie zestawu rur poza wagonem, połączenie ich $\mathrm{w}$ jednostkę montażową a następnie tylko przymocowanie do ostoi. Dotyczyć to oczywiście może tylko rur w części środkowej. Pozostałe muszą być układane krótkimi odcinkami odpowiednio ukształtowanymi, aby móc doprowadzić sprężone powietrze $\mathrm{w}$ rejon przede wszystkim wózka i kurków końcowych.

Doprowadzenie energii elektrycznej do wagonu odbywa się rurą WN przechodzącą wzdłuż całego wagonu. Z tej magistrali zasilana jest przetwornica statyczna, która przetwarza dostarczony prąd na odpowiedni rodzaj i napięcie. $Z$ przetwornicy poprzez kanał ka- blowy systemem rur elektroinstalacyjnych rozprowadzany jest prąd do poszczególnych urządzeń na podwoziu i w pudle.

Rura WN wykonana $\mathrm{z}$ aluminium przeprowadzona jest wzdłuż całego wagonu powyżej dolnej płaszczyzny ostoi, gdyż sposób mocowania urządzeń do podwozia ogranicza możliwość obniżenia jej położenia. Przechodzi więc przez otwory wykonane w pionowych ściankach elementów nośnych. Wymaga to montażu rury $\mathrm{WN}$ z krótkich odcinków, umożliwiających przekładanie ich przez te otwory. Najwygodniejszym rozwiązaniem byłoby przygotowanie całej rury i przymocowanie jej do dolnej płaszczyzny ostoi. Niestety podobnie jak w przypadku instalacji pneumatycznej nie jest to możliwe do wykonania na całej dhugości wagonu a jedynie w części środkowej. Mocowanie obecnie stosowanych urządzeń podwoziowych a zwłaszcza klimatyzacyjnych znacznie utrudnia przeprowadzenie rury WN poniżej dolnego poziomu ostoi. Utrudnia, ale nie jest niemożliwe. Wymagałoby to ewentualnie nieznacznego opuszczenia urządzeń podwoziowych w celu uzyskania większego odstępu pomiędzy obudową urządzenia a ostoją. Pojawia się jednak kolejne utrudnienie w postaci zarysu skrajni ograniczającej dolną część pojazdu. W takim przypadku należałoby zastanowić się nad możliwością zmiany kształtu przekroju rury WN z okraggego na np. prostokątny. Widać więc, że przeprowadzenie rury WN pod ostoją może wymagać indywidualnego dopasowania do zamocowanych urządzeń.

Kanał kablowy w ostatnio projektowanych konstrukcjach przeprowadzony jest wzdłuż korytarza. Koryto tego kanału stanowi część ryflowanej blachy podłogowej przykrytej od góry pokrywkami. Kanał znajduje się więc pod wyłożeniem podłogi i w związku z tym dostęp do niego jest nieco utrudniony. Najwygodniejszym rozwiązaniem byłoby umocowanie kanału kablowego pod ostoją poniżej dolnej płaszczyzny ostoi.

Części skrajne ze względu na współpracę wózka $\mathrm{z}$ ostoją właściwie uniemożliwiają przeprowadzenie jakiejkolwiek instalacji na poziomie dolnej płaszczyzny ostoi.

Z przeprowadzonych rozważań wynika, że korzystnym rozwiązaniem $\mathrm{z}$ punktu widzenia modułowej budowy ostoi byłoby zaprojektowanie swoistego rodzaju kanału, bądź zespołu kanałów, w których poprowadzonoby wszystkie główne instalacje wagonowe. Zespół taki mógłby być mocowany w części środkowej ostoi (między belkami skrętowymi) na poziomie dolnej płaszczyzny ostoi.

Problem unifikacji ostoi przypuszczalnie można rozwiązywać na wiele sposobów. W trakcie realizacji tematu powstała propozycja kolejnej koncepcji. Podstawowym założeniem jej jest zaprojektowanie takiej ostoi bazowej, która przenosić będzie wszystkie obciążenia eksploatacyjne a jednocześnie, zwłaszcza w części środkowej, będzie miała tak niskie przekroje 
poprzeczne, że w/w zestaw kanałów z instalacjami zmieściłby się od dołu wewnątrz ostoi i nie wystawałby poniżej dolnej jej płaszczyzny. Wówczas dolna płaszczyzna ostoi byłaby idealnym miejscem do montowania urządzeń podwoziowych za pomocą mniej lub bardziej uniwersalnych wsporników.

\section{Podsumowanie}

Reasumując można stwierdzić, że unifikacja konstrukcji ostoi to zagadnienie złożone, które na pewno można rozwiązywać różnymi drogami. Propozycje mogą dotyczyć tylko istniejącego stanu rozwoju konstrukcji. Problemu nie da się definitywnie zamknąć, gdyż trudno przewidzieć, jakie nowe rozwiązania konstrukcyjne poszczególnych urządzeń pojawią się na rynku.

\section{Literatura}

[1] Karta UIC 567, Postanowienia ogólne dla wagonów pasażerskich. Wydanie 2 z listopada 2004r.

[2] Karta UIC 567-2, Zunifikowane wagony pasażerskie typu $Z$ dopuszczone do ruchu międzynarodowego. Charakterystyki. Wydanie 4 z 01.07.1991r. ze zmiana $z$ 01.07.1995r.

[3] Opaliński Stanisław, Pudła współczesnych wagonów osobowych. Technika Transportu Szynowego nr 5/1997

[4] Cabos Hans-Peter, Werkstoffe für Schienenfahrzeuge. ETR-Eisenbahntechnische Rundschau 41(1992) H. 11

[5] Hondius Harry, Internationales Symposium Aluminium-Schienenfahrzeuge. Stadtverkehr 9/91 